\title{
Health effects of acrylonitrile in acrylic fibre factories
}

\author{
H. SAKURAI ${ }^{1}, M$. ONODERA ${ }^{1}$, T. UTSUNOMIYA ${ }^{2}$, H. MINAKUCHI ${ }^{2}$, H. IWAI $^{2}$, \\ AND H. MATSUMURA ${ }^{2}$ \\ From the ${ }^{1}$ Department of Preventive Medicine and Public Health, School of Medicine, Keio University, \\ and the ${ }^{2}$ Occupational Health Service Centre, Tokyo, Japan
}

ABSTRACT The relationship between the degree of exposure and biological effects of acrylonitrile (AN) was studied in 102 workers whose exposure period exceeded five years, and in 62 matched controls, all of whom had been randomly sampled from six acrylic fibre factories in Japan. The six factories were classified into three groups on the basis of AN concentration at workplaces. The most highly exposed group of subjects showed an eight-hour average AN concentration of $4.2 \mathrm{ppm}$ by personal sampling, a mean urinary AN concentration of $360 \mu \mathrm{g} / \mathrm{l}$ and a mean urinary thiocyanate concentration of $11.4 \mathrm{mg} / \mathrm{l}$. Medical examination, including the indocyanine green excretion test and multiple clinical chemistry determinations, failed to detect any health effect attributable to AN. Slight liver damage may possibly occur in more highly exposed workers. Urinary AN and thiocyanate determinations may provide more accurate estimates of low-grade exposure (less than $5 \mathrm{ppm}$ ).

Acrylonitrile (AN) has been used extensively since the 1940s with the rapid expansion of the petrochemical industry. Its acute toxicity has been found to be of a similar order to that of hydrogen cyanide (Dudley and Neal, 1942; Dudley et al., 1942), and many experimental studies have been performed to clarify whether acute toxic effects of AN are mediated by the production of cyanide ion in vivo or by the AN molecule itself (Dudley and Neal, 1942; Dudley et al., 1942; Brieger et al., 1952; Ghiringhelli, 1954; Hashimoto, 1959 a, b, c; Magos, 1962; Hashimoto and Kanai, 1965). Descriptions of acute poisoning caused by accidental exposure of humans are also found in the literature (Grunske, 1949; Lorz, 1950; Kondo, 1969; Radimer et al., 1974). However, there are relatively few reports on the health effects of AN other than in the acute form. No report yet published has reliably demonstrated the occurrence of chronic AN intoxication in man.

Several reports provide some evidence to suggest that slight liver damage occurs in workers exposed to AN (Wilson, 1944; Wilson et al., 1948; Suzuki, 1961; Kondo, 1969). Wilson (1944) and Wilson et al. (1948) described several cases of liver damage among AN workers engaged in the manufacture of synthetic rubber, but the description of the cases

Received for publication 26 September 1977 Accepted for publication 8 December 1977 was sketchy and the level and duration of exposure responsible were not clearly specified. Suzuki (1961) and Kondo (1969) found more subjective symptoms in AN workers than in control workers, and slight overall shifts of several liver function tests in the former group. However, they were unable to state categorically that any subject was suffering from liver damage because no distinctly abnormal findings were observed, nor were slightly abnormal findings for more than one test item observed in clusters. Similarly, Sakurai and Kusumoto (1972) analysed health examination records of AN workers from five acrylic fibre factories for a period of approximately 10 years up to 1970 and found that the prevalence of subjective complaints and abnormal values for some of the liver function tests increased significantly with increase in time spent at $\mathrm{AN}$ related jobs. They concluded that mild liver damage appeared to have been caused by AN exposure and expressed doubt about the adequacy of the current Threshold Limit Value (TLV) of $20 \mathrm{ppm}$ (American Conference of Governmental Industrial Hygienists, 1977). These reports, however, based their findings on routine health examinations and lacked adequate epidemiological design. Furthermore, exposure levels were not reliably reported.

We were recently given a unique opportunity to perform a health examination of AN workers together with an extensive evaluation of levels of 
exposure in all acrylic fibre factories in Japan. This study was carried out to discover whether subclinical effects, especially liver damage attributable to AN, could be observed among workers at these factories and to clarify the quantitative relationship between dose and effect, if any. Study subjects for both AN and control workers were selected by random sampling. Although recent suspicion of carcinogenicity of AN (National Institute for Occupational Safety and Health, 1977) was considered, the present report was limited to the clarification of health effects which could be detected mainly by multiple clinical chemistry determinations.

\section{Methods}

\section{SUBJECTS}

The study was performed between December 1975 and March 1976. Six out of the eight acrylic fibre factories belonging to seven different corporations in Japan were chosen for study, the two smallest being excluded.

Production of acrylic fibre began in the latter half of the 1950s in Japan. Output increased rapidly and rose to 335000 tonnes in 1973, about $21 \%$ of the world production in that year. In 1974 and 1975, however, the output decreased significantly because of economic setback. The output indices for these two years were $86.6 \%$ and $72.6 \%$ respectively, compared with the 1973 production level; that for the four-month period covered by this study was $87.0 \%$.

There were 1124 AN workers in all, and 571 nonAN workers were selected as controls. In order to minimise selection bias, all individuals involved in several non-AN production lines which were similar to acrylic fibre production lines in types of job and work shifts were included in the control population, which therefore comprised mainly employees from polyester fibre plants and power supply and finishing branches of acrylic fibre plants.

Of the $1124 \mathrm{AN}$ and 571 control workers, 296 and 360 men were selected respectively as study populations on the bases of exposure histories, types of shift or present occupation (Table 1).
From these study populations, stratified samples of $120 \mathrm{AN}$ and 60 control workers were obtained by randomly sampling $20 \mathrm{AN}$ and 10 age-matched control subjects from each of six factories.

The number of subjects who were given a health examination was 119 in the AN group and 58 in the control group, comprising $99.2 \%$ and $96.7 \%$ of each group respectively.

\section{EXPOSURE EVALUATION}

In addition to the measurement of $\mathrm{AN}$ concentration in spot samples of air at workplaces, the AN concentration in samples collected by personal samplers and free AN and thiocyanate ion concentrations in the urine of some workers were determined to evaluate individual exposure levels. The spot samplings were made on two consecutive days in each factory. An average of 101 samples (55-159) were taken for each factory. Acrylonitrile in air was analysed by a portable gas chromatograph.

The personal sampler consisted of a portable pump, a rotameter and a U-shaped glass tube filled with silica gel as adsorbent. The mean sampling time was about $100 \mathrm{~min} / \mathrm{sampler}$ and the daily time-weighted average concentration for each worker was calculated from the results of four successive personal samples. Acrylonitrile was desorbed in distilled water and determined by gas chromatography.

Urine was collected at the end of the working period. Acrylonitrile in urine was separated by azeotropic distillation (Sato et al., 1975) and determined by gas chromatography. The urinary thiocyanate ion concentration was determined by a modification (Sato et al., 1975) of the method reported by Aldridge (1944) and was corrected to a urinary specific gravity of 1.024 . It was also corrected to the smoking level of 15 cigarettes per day by the equation $T_{15}=T+0.15(15-x)$, where $x$ is the number of cigarettes smoked per day, and $T$ is the uncorrected thiocyanate ion concentration in $\mathrm{mg} / \mathrm{l}$, which was derived from the data of 46 control subjects whose smoking habit ranged from 0 to 30 cigarettes per day. Approximate detection limits for AN in spot samples at workplaces, AN in air

Table 1 Subjects selected as the study population

\begin{tabular}{|c|c|c|c|c|c|c|c|}
\hline \multirow{2}{*}{$\begin{array}{l}\text { Number of } \\
\text { subjects }\end{array}$} & \multirow{2}{*}{$\begin{array}{l}\text { Total } \\
\text { population }\end{array}$} & \multirow{2}{*}{$\begin{array}{l}\text { Study } \\
\text { population }\end{array}$} & \multicolumn{5}{|c|}{ Subjects excluded } \\
\hline & & & $\begin{array}{l}\text { History of } \\
\text { exposure to } \\
\text { toxic sub- } \\
\text { stances other } \\
\text { than } A N\end{array}$ & $\begin{array}{l}\text { Not on shift } \\
\text { work }\end{array}$ & $\begin{array}{l}\text { Administrative } \\
\text { position }\end{array}$ & $\begin{array}{l}\text { Length of } A N \\
\text { exposure }<5 \\
\text { years }\end{array}$ & $\begin{array}{l}\text { Total number } \\
\text { excluded }\end{array}$ \\
\hline $\begin{array}{l}\text { AN workers } \\
\text { Control workers }\end{array}$ & $\begin{array}{r}1124 \\
571\end{array}$ & $\begin{array}{l}296 \\
360\end{array}$ & $\begin{array}{l}333 \\
121\end{array}$ & $\begin{array}{l}384 \\
113\end{array}$ & $\begin{array}{l}4 \\
0\end{array}$ & $\begin{array}{l}453 \\
-\end{array}$ & $\begin{array}{l}828 \\
211\end{array}$ \\
\hline
\end{tabular}


collected by personal sampler and AN in urine were $1 \mathrm{ppm}, 0 \cdot 1 \mathrm{ppm}$ and $5 \mu \mathrm{g} / \mathrm{l}$ respectively.

Because personal sampling of air and collection of urine were performed on the same day as the health examination, those who underwent the health examinations were not necessarily the same as those whose air and urine were sampled.

\section{MEDICAL EXAMINATION}

Examination included past medical history, physical examination, work history, history of AN exposure, routine qualitative urinalyses, quantitative determination of urinary protein (Kuno and Kihara, 1967), indocyanine green excretion test (ICG) (Caesar et al., 1961), and multiple haematological examinations. Urine was collected on rising in the morning and blood was taken by venepuncture before breakfast. After the specific gravity of whole blood and the haemoglobin concentration had been determined, the plasma was separated, frozen with dry ice and taken to the Keio University Hospital laboratory where analyses were performed mostly with an auto-analysing system using routine methods.

Analyses included estimation of total protein and its fractions, direct and total bilirubin, total cholesterol, uric acid, urea nitrogen, creatinine, sodium, potassium, calcium, chloride, inorganic phosphate, zinc sulphate turbidity (ZTT), thymol turbidity test (TTT), aspartate aminotransferase (AsT), alanine transaminase (AIT), alkaline phosphatase, cholinesterase, leucine aminopeptidase (LAP), $\gamma$-glutamyl transpeptidase $(\gamma-\mathrm{GT})$, lactate dehydrogenase (LDH), and LDH isozymes. In the ICG test, only the 15 -min value was measured at the first factory. However, because the plasma concentration of the dye was too low at 15 minutes for adequate comparison to be made between exposed and control groups, 5-min and 10-min values were estimated for the remaining five factories. In all, quantitative comparisons could be made between AN and control groups with respect to 27 types of estimation.

\section{Results}

\section{EXPOSURE EVALUATION}

The six factories could be classified into three groups according to the levels of AN in the air at the workplaces. In the two best-controlled factories, most of the air samples contained less than $1 \mathrm{ppm} \mathrm{AN}$ and there were few results between 1 and $10 \mathrm{ppm}$. In three factories, about half the data recorded less than $1 \mathrm{ppm} \mathrm{AN}$, most other levels falling between 1 and $10 \mathrm{ppm}$, with a few samples showing concentrations as high as $100-200 \mathrm{ppm}$. In the remaining plant, most of the samples showed concentrations between 1 and $20 \mathrm{ppm}$, with a few samples indicating levels of over $100 \mathrm{ppm}$. When these three groups are named $\mathrm{A}, \mathrm{B}$, and $\mathrm{C}$ in order of increasing concentration, arithmetic means for the groups are $\mathrm{A}=2 \cdot 1 \mathrm{ppm}(\mathrm{N}=116) ; \mathrm{B}=7 \cdot 4 \mathrm{ppm}(\mathrm{N}=394)$; $\mathrm{C}=14 \cdot 1 \mathrm{ppm}(\mathrm{N}=98)$. The frequency distribution for factory $\mathrm{C}$ was approximately log-normal, and the geometric mean and geometric standard deviation for this factory were $4.97 \mathrm{ppm}$ and $4 \cdot 2$. Although the frequency distributions for $\mathrm{A}$ and $\mathrm{B}$ groups also appeared to be log-normal, many of the results for these groups were less than the detection limit of $1 \mathrm{ppm}$, and calculation of geometric means and standard deviations was not considered to be justified. Medians for A, B, and C groups were less than $1 \mathrm{ppm}, 1 \mathrm{ppm}$ and $5 \mathrm{ppm}$ respectively. Frequency distributions for AN in air collected by personal samplers, AN in urine, and thiocyanate in urine were also found to be approximately lognormal. Arithmetic means, and geometric means and geometric standard deviations when calculated, are shown in Table 2. Levels of individual exposure estimated by these indicators were found to correspond reasonably to the levels of exposure as expressed by AN concentration in the air.

\section{MEDICAL EXAMINATION}

Medical examinations were performed on 119 AN and 58 control workers. However, as a result of the interview, it was found that 13 of the $119 \mathrm{AN}$ workers had been exposed for less than five years, and four others had never been exposed to AN although they had been believed to be AN workers according to their job classification. Therefore, 13 men were excluded from the analysis because of their short exposure histories, and the other four were transferred to the control group. Thus the final number of subjects was 102 for the AN group and 62 for the control group.

Because the main purpose of the study was to investigate dose-related health effects of $\mathrm{AN}$, the subjects were also divided into three groups, A, B, and $C$, according to the degrees of exposure estimated for each factory. Means and standard deviations for age and length of AN exposure are shown in Table 3. The age distributions of the exposed and control subjects were well matched in each factory group. However, there were some differences in mean age of the groups; group $\mathrm{C}$ were the oldest $(38 \cdot 1 \mathrm{yr})$, followed by group B $(33.9 \mathrm{yr})$ and group $\mathrm{A}(30.5 \mathrm{yr})$. There was also a slight difference between group $\mathrm{C}$ and the other two groups in the mean length of exposure.

Medical histories did not suggest that any subject had been seriously affected by AN. However, many of the workers had initially experienced irritation of the conjunctiva and upper respiratory tract 
Table 2 Data for evaluation of AN exposure

\begin{tabular}{|c|c|c|c|c|c|c|c|c|c|c|c|c|c|c|c|c|c|c|}
\hline \multirow[t]{2}{*}{$\begin{array}{l}\text { Factory } \\
\text { group }\end{array}$} & \multirow[t]{2}{*}{$\begin{array}{l}\text { No. of } \\
\text { factories }\end{array}$} & \multicolumn{5}{|c|}{$\begin{array}{l}\text { AN concentration in spot samples } \\
\text { at workplaces }\end{array}$} & \multicolumn{4}{|c|}{$\begin{array}{l}\text { AN concentration in air } \\
\text { collected by personal sampler }\end{array}$} & \multicolumn{4}{|c|}{$A N$ concentration in urine } & \multicolumn{4}{|c|}{$\begin{array}{l}\text { Thiocyanate concentrat } \\
\text { urine }\end{array}$} \\
\hline & & $N$ & $\begin{array}{l}A M \\
(p p m)\end{array}$ & $\begin{array}{l}G M \\
(p p m)\end{array}$ & $G S D$ & $\begin{array}{l}\text { Median } \\
(\text { ppm })\end{array}$ & $N$ & $\begin{array}{l}A M \\
(p p m)\end{array}$ & $\begin{array}{l}G M \\
(p p m)\end{array}$ & $G S D$ & $N$ & $\begin{array}{l}A M \\
(\mu g / l)\end{array}$ & $\begin{array}{l}G M \\
(\mu g / l)\end{array}$ & $G S D$ & $N$ & $\begin{array}{l}A M \\
(m g / l)\end{array}$ & $\begin{array}{l}G M \\
(m g / l)\end{array}$ & $G$ s \\
\hline $\mathbf{A}$ & 2 & 116 & $2 \cdot 1$ & 一 & - & $<1 \cdot 0$ & 11 & $0 \cdot 1$ & 一 & - & 35 & $3 \cdot 9$ & - & - & 19 & $4 \cdot 50$ & $3 \cdot 76$ & 1.6 \\
\hline $\mathbf{B}$ & 3 & 394 & $7 \cdot 4$ & - & - & $1 \cdot 0$ & 37 & 0.5 & $0 \cdot 17$ & $4 \cdot 9$ & 51 & $19 \cdot 7$ & 10.9 & $3 \cdot 8$ & 58 & $5 \cdot 78$ & $5 \cdot 26$ & $1 \cdot t$ \\
\hline $\mathbf{C}$ & 1 & 98 & $14 \cdot 1$ & $4 \cdot 97$ & $4 \cdot 2$ & $5 \cdot 0$ & 14 & $4 \cdot 2$ & $3 \cdot 70$ & $1 \cdot 7$ & 22 & $359 \cdot 6$ & $105 \cdot 0$ & $4 \cdot 2$ & 24 & $11 \cdot 41$ & $9 \cdot 49$ & $2 \cdot($ \\
\hline Controls & 一 & - & - & - & - & - & - & - & - & - & 22 & 0 & - & - & 52 & $4 \cdot 00$ & $3 \cdot 05$ & $2 \cdot:$ \\
\hline
\end{tabular}

AM: arithmetic mean; GM: geometric mean; GSD: geometric standard deviation.

because of AN. A typical complaint was a runny nose when exposed to a high concentration of AN even for a short while. Some had even experienced transient irritation of the scrotal skin when they had worked inside polymerisation tanks using respiratory protectors. These acute irritative symptoms appear to have decreased gradually and had become infrequent by the time of this study.

Some typical data from the clinical chemistry determinations are listed in Table 4. Three phases of the ICG test, five isozymes of LDH, and five fractions of serum protein were compared separately, making the number of comparisons between the $\mathrm{AN}$ and control groups 35 in all. Analyses of variance indicated that there were no significant differences between control subjects in groups $\mathrm{A}, \mathrm{B}$, and $\mathrm{C}$ apart from data concerned with the serum creatinine concentration and $\alpha_{2}$ globulin fraction. For this reason, most data for AN groups were compared with total control subjects as shown in Table 4. Only for creatinine and $\alpha_{2}$ globulin were the results compared between AN and control subjects within each factory group. Statistically significant differences were found only in total cholesterol, alkaline phosphatase, creatinine, $\alpha_{2}$ globulin, and in ICG (10 min.). ICG showed a statistically significant difference only in the 10-minute data and, moreover, the difference was in the opposite direction to that which would be expected for adverse effects on the liver. Serum creatinine concentration in the exposed subjects was significantly higher in factory group B, but was, conversely, significantly lower in the most highly exposed factory group $\mathrm{C}$. These sporadic occurrences of statistically significant differences may have been caused merely by chance, because the total number of comparisons between the exposed and control subjects amounted to 133 . It is notable that there was no significant difference that could be attributed to $\mathrm{AN}$ in the most highly exposed group C. When results were compared for factory groups $\mathrm{A}, \mathrm{B}$, and $\mathrm{C}$, no test item was found to show a dose-related change suggestive of any effects of AN.

Table 5 shows some of the findings of the physical examination. Palpable liver was considerably more prevalent in the exposed subjects than in control subjects in all factory groups, but not to a statistically significant extent. Reddening of conjunctiva or pharynx, and rashes or skin pigmentation were also slightly more prevalent in the exposed subjects, but again the differences were not significant. Even when comparisons were made between all $\mathrm{AN}$ and control subjects for these findings, the differences were not statistically significant. Results of liver function tests for $20 \mathrm{AN}$ workers whose livers were palpable were compared with those of all $\mathrm{AN}$ and control workers. However, no supportive evidence could be found to indicate that hepatic function of the exposed workers whose livers were palpable had been affected by AN. Other clinical tests such as blood pressure and neurological findings did not show any difference between $\mathrm{AN}$ and control groups.

\section{Discussion}

Because the protocol for the sampling of subjects was very carefully designed and carried out much

Table 3 Age and length of $A N$ exposure (mean \pm standard deviation)

\begin{tabular}{|c|c|c|c|c|c|c|}
\hline \multirow[t]{2}{*}{ Variables } & \multicolumn{2}{|c|}{$\begin{array}{l}\text { Factory group } \\
A\end{array}$} & \multicolumn{2}{|l|}{$\boldsymbol{B}$} & \multicolumn{2}{|l|}{$C$} \\
\hline & $\begin{array}{l}A N \text { workers } \\
(N=31)\end{array}$ & $\begin{array}{l}\text { Controls } \\
(N=22)\end{array}$ & $\begin{array}{l}A N \text { workers } \\
(N=53)\end{array}$ & $\begin{array}{c}\text { Controls } \\
(N=30)\end{array}$ & $\begin{array}{l}\text { AN workers } \\
(N=18)\end{array}$ & $\begin{array}{l}\text { Controls } \\
(N=10)\end{array}$ \\
\hline $\begin{array}{l}\text { Age } \\
\text { Length of AN exposure }\end{array}$ & $\begin{array}{l}30 \cdot 5 \pm 3 \cdot 9 \\
10 \cdot 3 \pm 4 \cdot 5\end{array}$ & $\underline{30 \cdot 1} \pm 4 \cdot 2$ & $\begin{array}{l}33.9 \pm 5.8 \\
10.8 \pm 4.4\end{array}$ & $\begin{array}{l}33.4 \\
-\end{array}$ & $\begin{array}{l}38 \cdot 1 \pm 5 \cdot 9 \\
12 \cdot 6 \pm 2 \cdot 1\end{array}$ & $\underline{38 \cdot 0 \pm 5 \cdot 7}$ \\
\hline
\end{tabular}


Table 4 Data selected from multiple clinical chemistry determinations

\begin{tabular}{|c|c|c|c|c|c|c|c|c|c|c|c|c|c|c|c|}
\hline \multirow[t]{2}{*}{ Estimation } & \multirow[t]{2}{*}{ Subject group } & \multicolumn{3}{|c|}{$\begin{array}{l}\text { Factory group } \\
A\end{array}$} & \multicolumn{4}{|l|}{$\boldsymbol{B}$} & \multicolumn{4}{|l|}{$C$} & \multirow{2}{*}{\multicolumn{2}{|c|}{$\begin{array}{l}\text { Total } \\
\text { Mean } \pm S E\end{array}$}} & \multirow[t]{2}{*}{$N$} \\
\hline & & Mean & $\pm S E$ & $\boldsymbol{N}$ & Mean & $n \pm$ & $S E$ & $N$ & Mean & \pm & $S E$ & $N$ & & & \\
\hline Urinary protein $(\mu \mathrm{g} / \mathrm{ml})$ & $\begin{array}{l}\text { AN } \\
\text { Control }\end{array}$ & $75 \cdot 5$ & $\pm 8 \cdot 6$ & 31 & $90 \cdot 4$ & \pm 1 & $16 \cdot 1$ & 53 & $87 \cdot 6$ & \pm 1 & $15 \cdot 5$ & 18 & $\begin{array}{r}85 \cdot 4 \\
104 \cdot 8\end{array}$ & $\begin{array}{l} \pm 33.6 \\
\pm 20.4\end{array}$ & $\begin{array}{r}102 \\
62\end{array}$ \\
\hline Haemoglobin (g/dl) & $\begin{array}{l}\text { AN } \\
\text { Control }\end{array}$ & $15 \cdot 1$ & \pm 0.25 & 30 & $15 \cdot 7$ & \pm & $0 \cdot 19$ & 53 & $15 \cdot 1$ & \pm & $0 \cdot 26$ & 18 & $\begin{array}{l}15 \cdot 4 \\
15 \cdot 3\end{array}$ & $\begin{array}{ll} \pm & 0.14 \\
\pm & 0.16\end{array}$ & $\begin{array}{r}101 \\
62\end{array}$ \\
\hline Total bilirubin (mg/dl) & $\begin{array}{l}\text { AN } \\
\text { Control }\end{array}$ & $0 \cdot 82$ & \pm 0.08 & 28 & 0.88 & \pm & 0.06 & 38 & 0.92 & \pm & $0 \cdot 15$ & 12 & $\begin{array}{l}0.86 \\
0.81\end{array}$ & $\begin{array}{l} \pm 0.05 \\
\pm 0.05\end{array}$ & $\begin{array}{l}78 \\
45\end{array}$ \\
\hline Total cholesterol (mg/dl) & $\begin{array}{l}\text { AN } \\
\text { Control }\end{array}$ & $* 202$ & $\pm 6 \cdot 3$ & 31 & 210 & \pm & $5 \cdot 7$ & 53 & 212 & \pm & $5 \cdot 7$ & 18 & $\begin{array}{r}208 \\
220\end{array}$ & $\begin{array}{l} \pm 3.6 \\
\pm \quad 4.8\end{array}$ & $\begin{array}{r}102 \\
61\end{array}$ \\
\hline Zinc sulphate turbidity (unit) & $\begin{array}{l}\text { AN } \\
\text { Control }\end{array}$ & $7 \cdot 9$ & \pm 0.59 & 31 & $7 \cdot 3$ & \pm & 0.55 & 46 & $7 \cdot 5$ & \pm & 0.85 & 18 & $\begin{array}{l}7.6 \\
7.4\end{array}$ & $\begin{array}{ll} \pm & 0.38 \\
\pm & 0.44\end{array}$ & $\begin{array}{l}95 \\
49\end{array}$ \\
\hline AsT (unit) & $\begin{array}{l}\text { AN } \\
\text { Control }\end{array}$ & $21 \cdot 1$ & $\pm 1 \cdot 5$ & 31 & $21 \cdot 7$ & \pm & 0.9 & 53 & $19 \cdot 9$ & \pm & $1 \cdot 0$ & 18 & $\begin{array}{l}21 \cdot 2 \\
21 \cdot 7\end{array}$ & $\begin{array}{l} \pm 0.7 \\
\pm \quad 1.0\end{array}$ & $\begin{array}{r}102 \\
62\end{array}$ \\
\hline AIT (unit) & $\begin{array}{l}\text { AN } \\
\text { Control }\end{array}$ & $15 \cdot 3$ & \pm 1.9 & 31 & $14 \cdot 3$ & \pm & $1 \cdot 1$ & 53 & $10 \cdot 5$ & \pm & $1 \cdot 1$ & 18 & $\begin{array}{l}13 \cdot 9 \\
13 \cdot 7\end{array}$ & $\begin{array}{ll} \pm & 0.8 \\
\pm & 1.4\end{array}$ & $\begin{array}{r}102 \\
62\end{array}$ \\
\hline Alkaline phosphatase (unit) & $\begin{array}{l}\text { AN } \\
\text { Control }\end{array}$ & $* 4 \cdot 4$ & $\pm 0 \cdot 17$ & 31 & $5 \cdot 6$ & \pm & $0 \cdot 21$ & 53 & $5 \cdot 4$ & \pm & 0.59 & 18 & $\begin{array}{l}5 \cdot 2 \\
5 \cdot 1\end{array}$ & $\begin{array}{l} \pm 0.17 \\
\pm \quad 0.17\end{array}$ & $\begin{array}{r}102 \\
62\end{array}$ \\
\hline$\gamma$-GT (unit) & AN & $17 \cdot 5$ & $\pm 3 \cdot 1$ & 31 & $15 \cdot 1$ & \pm & $2 \cdot 1$ & 53 & $14 \cdot 7$ & \pm & $1 \cdot 9$ & 18 & $\begin{array}{l}15 \cdot 7 \\
17 \cdot 3\end{array}$ & $\begin{array}{l} \pm 1 \cdot 5 \\
\pm \quad 2 \cdot 4\end{array}$ & $\begin{array}{r}102 \\
62\end{array}$ \\
\hline $\begin{array}{l}\text { Creatinine }(\mathrm{mg} / \mathrm{dl}) \\
\alpha_{2} \text { globulin }(\%)\end{array}$ & $\begin{array}{l}\text { AN } \\
\text { Control } \\
\text { AN } \\
\text { Control }\end{array}$ & $\begin{array}{l}0 \cdot 84 \\
0 \cdot 86 \\
8 \cdot 1 \\
7 \cdot 7\end{array}$ & $\begin{array}{l} \pm 0.023 \\
\pm 0.020 \\
\pm 0.28 \\
\pm 0.19\end{array}$ & $\begin{array}{l}31 \\
22 \\
31 \\
22\end{array}$ & $\begin{array}{r}0.89 \\
* 0.82 \\
6.7 \\
* 7.6\end{array}$ & $\begin{array}{l} \pm \\
\pm \\
\pm \\
\pm\end{array}$ & $\begin{array}{l}0.017 \\
0.021 \\
0.16 \\
0.22\end{array}$ & $\begin{array}{l}50 \\
27 \\
53 \\
30\end{array}$ & $\begin{array}{r}0.93 \\
* 1.06 \\
7.8 \\
8.6\end{array}$ & $\begin{array}{l} \pm \\
\pm \\
\pm \\
\pm\end{array}$ & $\begin{array}{l}0.021 \\
0.041 \\
0.44 \\
0.34\end{array}$ & $\begin{array}{l}18 \\
10 \\
18 \\
10\end{array}$ & & & \\
\hline ICG 5 min. $(\%)$ & $\begin{array}{l}\text { AN } \\
\text { Control }\end{array}$ & $42 \cdot 1$ & $\pm 2 \cdot 2$ & 30 & $43 \cdot 6$ & $\overline{ \pm}$ & 1.9 & 51 & - & & & - & $\begin{array}{l}43 \cdot 1 \\
47 \cdot 5\end{array}$ & $\begin{array}{l} \pm 1 \cdot 4 \\
\pm \quad 2 \cdot 0\end{array}$ & $\begin{array}{l}81 \\
50\end{array}$ \\
\hline ICG 10 min. $(\%)$ & $\begin{array}{l}\text { AN } \\
\text { Control }\end{array}$ & $15 \cdot 5$ & $\pm 1 \cdot 1$ & 29 & $16 \cdot 1$ & \pm & $1 \cdot 0$ & 48 & - & & & - & $\begin{array}{r}* 15.9 \\
19.1\end{array}$ & $\begin{array}{l} \pm 0.7 \\
\pm \quad 1.5\end{array}$ & $\begin{array}{l}77 \\
51\end{array}$ \\
\hline ICG $15 \mathrm{~min} .(\%)$ & $\begin{array}{l}\text { AN } \\
\text { Control }\end{array}$ & - & & - & - & & & - & $\begin{array}{l}7 \cdot 2 \\
5 \cdot 3\end{array}$ & $\begin{array}{l} \pm \\
\pm\end{array}$ & $\begin{array}{l}1 \cdot 25 \\
0.33\end{array}$ & $\begin{array}{r}11 \\
9\end{array}$ & & & \\
\hline
\end{tabular}

$* \mathbf{P}<0.05$

more strictly than is usual in this kind of field study, it may be safely concluded that even those subclinical effects that can be detected by the ICG test or multiple laboratory examinations did not exist at the time of the present study in acrylic fibre factories in Japan. Slightly higher prevalences of some of the objective findings cannot be regarded as evidence of adverse effects of AN because the differences were not statistically significant and no supportive data were obtained from laboratory examinations. The reason for the unusually high prevalence of irritative signs and palpable liver both for $\mathrm{AN}$ and control subjects at factory $\mathrm{C}$ is not clear. Because factory $\mathrm{C}$ was situated apart from other factories, these findings may possibly have resulted from an outbreak of upper respiratory infection or some local peculiarities such as drinking habits. Moreover, an apparently higher prevalence in AN subjects could have been related to examiner bias because the study was not designed to make the examiner blind to the exposure status of each subject. However, the possibility cannot be entirely excluded that findings such as palpable liver and reddening of the conjunctiva or pharynx were signs of AN exposure at factory C. Further study with a larger sample is necessary to investigate these possibilities.

It may be that less fit AN workers had been

le 5 Prevalence of various physical signs

\begin{tabular}{|c|c|c|c|c|c|c|c|c|c|c|c|c|c|}
\hline & & \multicolumn{3}{|c|}{${ }_{A}^{\text {Factory group }}$} & \multicolumn{3}{|l|}{$B$} & \multicolumn{3}{|l|}{$C$} & \multicolumn{3}{|c|}{ Total } \\
\hline & & No. & $\begin{array}{l}\text { Rate } \\
(\%)\end{array}$ & Significance* & No. & $\begin{array}{l}\text { Rate } \\
(\%)\end{array}$ & Significance* & No. & $\begin{array}{l}\text { Rate } \\
(\%)\end{array}$ & Significance* & No. & $\begin{array}{l}\text { Rate } \\
(\%)\end{array}$ & Significance* \\
\hline $\begin{array}{l}\text { dening of conjunctiva } \\
\text { pharynx } \\
\text { able liver } \\
\text { les or pigmentation } \\
\text { the skin }\end{array}$ & $\begin{array}{l}\text { AN } \\
\text { Control } \\
\text { AN } \\
\text { Control } \\
\text { AN } \\
\text { Control }\end{array}$ & $\begin{array}{l}31 \\
22 \\
31 \\
22 \\
31 \\
22\end{array}$ & $\begin{array}{r}19 \cdot 4 \\
18 \cdot 2 \\
16 \cdot 1 \\
9 \cdot 1 \\
9 \cdot 7 \\
9 \cdot 1\end{array}$ & $\begin{array}{l}\text { NS } \\
\text { NS } \\
\text { NS }\end{array}$ & $\begin{array}{l}53 \\
30 \\
53 \\
30 \\
53 \\
30\end{array}$ & $\begin{array}{l}11 \cdot 3 \\
10 \cdot 0 \\
15 \cdot 1 \\
10 \cdot 0 \\
3 \cdot 8 \\
0\end{array}$ & $\begin{array}{l}\text { NS } \\
\text { NS } \\
\text { NS }\end{array}$ & $\begin{array}{l}18 \\
10 \\
18 \\
10 \\
18 \\
10\end{array}$ & $\begin{array}{l}50 \cdot 0 \\
30 \cdot 0 \\
38 \cdot 9 \\
30 \cdot 0 \\
11 \cdot 0 \\
0\end{array}$ & $\begin{array}{l}\text { NS } \\
\text { NS } \\
\text { NS }\end{array}$ & $\begin{array}{r}102 \\
62 \\
102 \\
62 \\
102 \\
62\end{array}$ & $\begin{array}{r}20 \cdot 6 \\
16 \cdot 1 \\
19 \cdot 6 \\
12 \cdot 9 \\
6 \cdot 9 \\
3 \cdot 2\end{array}$ & $\begin{array}{l}\text { NS } \\
\text { NS } \\
\text { NS }\end{array}$ \\
\hline
\end{tabular}

o-tailed tests of significance by $Z$ test with Yates' correction or by Fisher's exact method. 
transferred from shift to day work, and thus a bias was introduced into this shift-orientated study. However, it is still considered that some positive laboratory findings would have been obtained if there had been hepatotoxic levels of AN exposure during the period of study.

Although data obtained from medical examination were negative, they are of considerable value when referring to the levels of exposure, as shown in Table 2. No report has so far offered reliable data on the concentration of AN at workplaces. Hence, the dose-response relationship between $\mathrm{AN}$ and humans has been obscure. According to the literature published by The American Conference of Governmental Industrial Hygienists (1966), the threshold limit value of $20 \mathrm{ppm}$ recommended for AN was derived from only two animal experiments (Dudley and Neal, 1942; Dudley et al., 1942). The results of our study may provide a 'no observed effect' level for human exposure at work as far as liver damage and the other health effects detectable by the multiple laboratory examinations used in this study are concerned.

The methods of exposure evaluation used here are considered to be sufficiently accurate to make reasonable estimates of the levels of exposure in acrylic fibre factories in Japan at the time of the study. Because complete randomisation of air sampling sites was not possible, there may have been some tendency for more samples to be taken at places near AN emission sources. This may have been the case in particular for factory group $\mathrm{C}$ where we started this series of surveys. However, a large number of samples were taken (Table 2) and these were made fairly evenly throughout workdays. The data cited as the concentration of AN in spot samples in Table 2 may be considered to be reasonable estimates of the exposure of the workers assuming that they were at that location all day. However, the workers actually spent much of their working time in monitoring and waiting rooms where exposure was non-existent. Hence, the concentration of AN in personally sampled air was considerably lower than that in spot air samples as shown in Table 2. The levels of actual exposure of the subjects in this study probably approximated to the values obtained by the personal sampling. This was as low as $0.1 \mathrm{ppm}$ for factory group $A$ and only $4.2 \mathrm{ppm}$ even for factory C. Urinary AN and thiocyanate ion concentrations may offer more accurate estimates of levels of such low-grade exposure. In summary, it is concluded that time-weighted average exposure of the most highly exposed group in this study may not have been over $5 \mathrm{ppm}$, but it was this level which induced an average urinary AN concentration of $360 \mu \mathrm{g} / 1$ and an average urinary thiocyanate ion concentration of $11.4 \mathrm{mg} / \mathrm{l}$.

It is questionable whether exposure at the time of the study was comparable to that in the past. Production levels during the study period were lower than those in previous years for all factories. Moreover, we learned from factory administrators and subjects that almost all factories had undergone considerable improvements in the working environment about five years before this study. Enclosure of emission sources and installation of exhaust ventilation apparently contributed to some extent to the improvement. However, a more important cause for the reduction of workers' exposure appears to have been a reduction in the number of mechanical faults resulting from efforts to raise productivity. This apparently lessened the risk of being exposed to unusually high concentrations of AN. Considering all these factors, past levels of exposure were probably higher than the levels found in this study. The failure of this study to detect adverse effects attributable to AN does not, therefore, contradict previous results (Wilson, 1944; Wilson et al., 1948; Suzuki, 1961; Kondo, 1969; Sakurai and Kusumoto, 1972), which suggested that liver damage had occurred in workers who apparently had been exposed to higher concentrations. Of special interest is the report by Sakurai and Kusumoto (1972) which showed slight increases in the prevalence of abnormal values for some liver function tests among AN workers from the same factories as those in the present report. As this observation was made in the 10 years before 1970 , the negative results in the present report may be explained by a subsequent decrease in exposure.

As shown in Table 2, both AN and thiocyanate concentrations in urine were found to be useful indicators of AN exposure. Urinary AN concentrations were high even in low-grade exposure. Although the method of analysing urinary AN in this study is not convenient for routine use, it may be a useful indicator of individual lower-grade exposure. On the other hand, urinary thiocyanate ion concentration may be useful only in evaluating levels of exposure on a group basis, because thiocyanate exists in normal urine and increases with smoking. The value listed in Table 2 has been corrected to a mean smoking level of 15 cigarettes per day and a mean urinary specific gravity of $1 \cdot 024$. However, thiocyanate determination is relatively simple compared with AN determination. This study did not attempt to deal with the problem of carcinogenicity. If, however, a more careful approach is needed for the prevention of AN exposure because of its suspected carcinogenicity (National Institute for Occupational Safety and Health, 1977) measurements of these indicators will be of considerable 
practical value. Dose-effect relationships between AN concentration in air and urinary AN or thiocyanate ion excretion in humans have not been reported elsewhere. Further data from field surveys are obviously needed.

We are grateful to Japan Chemical Fibres Association and the members of its Committee on Industrial Health for their cooperation throughout this study; to Dr J. Kubota, Director of the Occupational Health Service Centre, and Professor T. Toyama, Keio University School of Medicine, for valuable help and advice.

\section{References}

Aldridge, W. N. (1944). A new method for the estimation of micro quantities of cyanide and thiocyanate. Analyst, 69, 262-265.

American Conference of Governmental Industrial Hygienists (1966). Documentation of Threshold Limit Values, Revised edition, p. 5. ACGIH: Cincinnati.

American Conference of Governmental Industrial Hygienists (1977). Threshold Limit Values for Chemical Substances and Physical Agents in the Workroom Environment. ACGIH: Cincinnati.

Brieger, H., Rieders, F., and Hodes, W. A. (1952). Acrylonitrile: spectrophotometric determination, acute toxicity, and mechanism of action. Archives of Industrial Hygiene and Occupational Medicine, 6, 128-140.

Caesar, J., Shaldon, S., Chiandussi, L., Guevara, L., and Sherlock, S. (1961). The use of indocyanine green in the measurement of hepatic blood flow and as a test of hepatic function. Clinical Science, 21, 43-57.

Dudley, H. C., and Neal, P. A. (1942). Toxicology of acrylonitrile (vinyl cyanide). I. A study of the acute toxicity. Journal of Industrial Hygiene and Toxicology, 24, 27-36.

Dudley, H. C., Sweeney, T. R., and Miller, J. W. (1942). Toxicology of acrylonitrile (vinyl cyanide). II. Study of effects of daily inhalation. Journal of Industrial Hygiene and Toxicology, 24, 255-258.

Ghiringhelli, L. (1954). Nitrile acrilico: tossicitá e meccanismo d'azione. La Medicina del Lavoro, 45, 305-312.

Grunske, F. (1949). Ventox und Ventox-Vergiftung. Deutsche Medizinische Wochenschrift, 74, 1081-1083.
Hashimoto, K. (1959a). Studies on the intoxication o acrylonitrile. I. Effect of acrylonitrile on respiratory functions of the whole body. Quarterly Journal of Labour Research, 7, 7-12. (In Japanese, with English abstract.)

Hashimoto, K. (1959b). Studies on the intoxication of acrylonitrile. II. Detection of cyanide and thiocyanate from blood and urine. Quarterly Journal of Labour Research, 7, 13-18. (In Japanese, with English abstract.)

Hashimoto, K. (1959c). Studies on the intoxication of acrylonitrile. III. Action of acrylonitrile on the conduction of impulse in peripheral motor nerve. Quarterly Journal of Labour Research, 7, 19-22. (In Japanese, with English abstract.)

Hashimoto. K., and Kanai, R. (1965). Studies on the toxicology of acrylonitrile. Metabolism, mode of action and therapy. Industrial Health, 3, 30-46.

Kondo, H. (1969). Health care of acrylonitrile workers. Rodo Eisei, 3 (5), 21-25. (In Japanese.)

Kuno, H., and Kihara, H. K. (1967). Simple microassay of protein with membrane filter. Nature, 215, 974-975.

Lorz, H. (1950). Über perkutane Vergiftung mit Akrylnitril (Ventox). Deutsche Medizinische Wochenschrift, 75, 1087-1088.

Magos, L. (1962). A study of acrylonitrile poisoning in relation to methaemoglobin-CN complex formation. British Journal of Industrial Medicine, 19, 283-285.

National Institute for Occupational Safety and Health (1977). Acrylonitrile. Current Intelligence Bulletin of NIOSH, July 1, 1-4. USPHS: Rockville.

Radimer, G. F., Davis, J. H., and Ackerman, A. B. (1974). Fumigant-induced toxic epidermal necrolysis. Archives of Dermatology, 110, 103-104.

Sakurai, H., and Kusumoto, M. (1972). Epidemiological study of health impairment among acrylonitrile workers. Journal of Science of Labour, 48, 273-282. (In Japanese, with English abstract.)

Sato, M., Ishizu, S., and Momotani, H. (1975). Determination of acrylonitrile, cyanide and thiocyanate in blood and urine. Japanese Journal of Industrial Health, 17, 99-105. (In Japanese, with English abstract.)

Suzuki, T. (1961). Studies on occupational diseases in synthetic resin industries. II. A study of acrylonitrile intoxication. Journal of Kansai Medical School, 13, 545-551. (In Japanese.)

Wilson, R. H. (1944). Health hazards encountered in the manufacture of synthetic rubber. Journal of the American Medical Association, 124, 701-702.

Wilson, R. H., Hough, G. V., and McCormick, W. E. (1948). Medical problems encountered in the manufacture of American-made rubber. Industrial Medicine and Surgery, 17, 199-200. 